\title{
Analysis of Volatile Organic Compounds from the Aerial Parts of Medicinal Plant, Galium verum
}

\author{
IRINA CIOTLAUS, MARIA POJAR-FENESAN, ANA BALEA*
}

Babes-Bolyai University, "Raluca Ripan" Institute of Research in Chemistry, 30 Fantanele Str., 400294, Cluj-Napoca, Romania

\begin{abstract}
The Galium verum herb, (Rubiaceae family) is well represented in the spontaneous Romanian flora. She is one of the most used plants in traditional medicine. Our research aimed to investigate the chemical volatile profile in fresh, dried and essential oil of Gallium verum using SPME and hydrodistillation techniques, followed by GC-MS analysis. Characterization of volatile compounds composition by SPME-GC-MS technique presented din this paper is the first study on fresh and dried of Galium verum plant to our knowledge. Galium verum fresh flower floral bouquet is given by monoterpenes $(73,5 \%)$, sesquiterpenes $(10,16 \%)$, esters $(10,26 \%)$ and others $(5.87 \%)$. The floral bouquet of Gallium verum dried flower, contains mainly: aldehydes (35.48\%) monoterpenes (35.48\%), alcohols (11.96\%), sesquiterpenes, (3.71\%), esters (3.14\%) and others (10.11\%). Sixty components were identified in the galium essential oil.
\end{abstract}

Keywords: Gallium verum, volatile organic compound, SPME, essential oil, GC-MS

\section{Introduction}

In the last period, more and more people are choosing natural products to treat certain diseases. Galium verum L., (yellow bedstraw) is an herbaceous perennial, belonging to the Rubiaceae family, noted for their yellow-golden flowers, with think and rich inflorescences, and a very pleasant smell [1]. This plant spread throughout in all Europe, but also in North Africa and Asia. The genus Galium is well represented in the spontaneous Romanian flora, there are between twenty-eight and thirty-five species, with white and yellow flowers. [2]. She is one of the most used plants in traditional medicine from ancient times until now. Most of these species have been extensively investigated for antraquinones [3] and iridoids [4, 5] but little is known about other bioactive compounds classes. The plant contains flavonoids, small amounts of iridoid, glycosides, phenolics, [6-8] flavonoids, [9, 10] carbohydrates, tannins, enzymes which coagulate animal milk, amino acids and essential oil [11]. Galium verum possessed antioxidant, cytotoxic, antimicrobial, protective and endocrine effects. [12, 13] Today this plant is used in the treatment of many diseases, due to its sudorific and diuretic effects, choleretics, against diarrhea and in the treatment of some stomach complaints, respiratory and skin diseases, but also in cosmetics [14]. Can be used both internally, in the form of powder, tincture, macerate, tea, and externally, in the form of extract and ointment. [15]. Alleged medical benefits of the plant in folk medicine are numerous, but research nowadays focuses on cancer therapy [16].

Solid phase microextraction (SPME) technique was introduced the first time by Pawliszyn. [17] SPME technique is a more, rapid, sensitive, and solvent free compared to traditional methods for analyzing the fraction of volatile compounds in different matrices. SPME has been successfully utilized for a qualitative analysis of volatile components from various aromatic and medicinal plants. [18-21]. Studies on the chemical volatile profile in fresh and dried Galium verum plant have not been reported in the literature. There are few studies on Gallium verum oil composition. Extraction of essential oil was carried out by hydrodistillation, using a Clevenger-type apparatus. The main

*email: ana.balea@yahoo.com 
components previously identified in Galium verum oil are: caryophyllene, caryophyllene oxide, germacrene D [22], cis-3-hexenol, benzyl alcohol, squalene [23], phytol, tetradecane, hexadecane, 9,12,15-octadecatrienoic acid-methyl ester, hexadecanoic acid-methyl ester.[24] The volatiles composition influences the bioactivity of aromatic herbs and the essential oils produced from these.

There are comparative studies on different medicinal herbs between volatiles extracted from fresh living material and essential oil obtained from the same plant. [25-30].

Our research aimed to investigate the chemical volatile profile in Gallium verum fresh, dried and essential oil using SPME and hydrodistillation techniques (HD), followed by of gas-chromatography mass spectrometry (GC-MS) analysis. Characterization of volatile organic compounds (VOCs) by SPME -GC-MS technique presented in this paper is the first study on Galium verum plant, fresh and dried to our knowledge.

\section{Materials and methods \\ 1. Plant material}

The fresh of Galium verum plant (fam. Rubiaceae) were collected during full flowering stage from the wild Romanian flora (Cluj county), in June 2019. The vegetal herbal material was air dried at room temperature in shade, in thin layers, in a well-ventilated place until they reached a constant weight. From $3.5 \mathrm{~kg}$ fresh plant $1 \mathrm{~kg}$ of dry matter was obtained. The plant was identified in accordance with the specialized literature. $[1,2]$

\section{2. a. Solid phase microextraction (SPME)}

In order to develop a SPME procedure for the isolation of Galium verum plant headspace volatiles, the optimisation of parameters influencing this process such as fibre coating, extraction time and temperature was carried out. The fresh and dried of Galium verum plant were subjected to chemoprofiling using by solid phase microextraction (SPME) coupled with gas-chromatograph-mass spectrometer (GC-MS). The sample $(1 \mathrm{~g})$ together with distilled water $(8 \mathrm{~mL})$ was placed in a $20 \mathrm{~mL}$ vial and closed by a cap with a teflon septum. The vials were placed in a water bath with a temperature of $50-55^{\circ} \mathrm{C}$ for 15 minutes to disperse and release the volatiles from the matrix. The fiber used was Carboxen /PDMS $75 \mu \mathrm{m}$. (Supelco). The preconditioned SPME fiber $\left(270^{\circ} \mathrm{C}, 1 \mathrm{~h}\right)$ in the GC-injector port was inserted into the head space of the vial containing the sample. Heating of the sample continue 20 min during collection/adsorption. The fiber was then retracted and inserted into the injector of GCMS. Desorption was performed for $10 \mathrm{~min}$ with the injector at $240^{\circ} \mathrm{C}$.

\section{b.GC- MS analysis}

Identification of the volatile compounds was performed using on instrument Model Agilent 7890 \& 5975 Series MSD, equipped with a HP-5MS (5\% phenyl )-methyl polysiloxane fused silica column Agilent $(30 \mathrm{~m} \times 0.25 \mathrm{~mm} \times 0.25 \mu \mathrm{M})$. GC-MS data was obtained under the following conditions: carrier gas helium (He 6.0), flow rate $1 \mathrm{ml} / \mathrm{min}$, injector temperature was $260^{\circ} \mathrm{C}$, splitless mode. The temperature program was the following: Oven temperature was programmed as $40^{\circ} \mathrm{C}$ for 1 min and an increase by $5{ }^{\circ} \mathrm{C} / \mathrm{min}$ to $200{ }^{\circ} \mathrm{C}$. From $200{ }^{\circ} \mathrm{C}$ to $240{ }^{\circ} \mathrm{C}$, increase with $20{ }^{\circ} \mathrm{C} / \mathrm{min}$. It is maintained at $240{ }^{\circ} \mathrm{C}$ for 5 minutes. Mass spectra: electron impact (EI+) mode, $70 \mathrm{eV}$ and ion source temperature, $230^{\circ} \mathrm{C}$. Mass spectra were recorded over 50-500 a.m.u.range, scan mode. All analyses were carried out in duplicate. Data acquisition and processing were performed using MSD ChemStation software. NIST library was used for identification/ confirmation of the structure components In addition, a $\mathrm{C}_{8}-\mathrm{C}_{20}$ standards alkanes (Alkane Standard Solution $\mathrm{C}_{8}-\mathrm{C}_{20}$, Sigma Aldrich) was used for calculation of the linear retention index (RI), and matching the experimental values with those reported in the literature for similar chromatographic columns, in the same condition. For compounds with RT $<5.690$ and RT $>$ 29.978, KI was reported from Nist Library Spectra. 


\section{3. a. Extraction of Essential Oil by Hydrodistillation Method (HD)}

The aerial parts of Galium verum were dried in shadow at room temperature for one week, cut into pieces of size over the range $1-4 \mathrm{~cm}$ and grounded to a homogeneous powder. Extraction of essential oil was carried out by hydrodistillation, using a Clevenger-type apparatus.Two distillations were carried out by boiling $100 \mathrm{~g}$ of dried leaves of Galium verum in 1liter of distilled water during $3 \mathrm{~h}$, the yield of essential oil was determined in relation to the dry matter $(1,1 \% \mathrm{w} / \mathrm{w})$. The yellowish oil obtained was collected and dried over anhydrous $\mathrm{MgSO} 4$, and stored in dark glass bottles at $4{ }^{\circ} \mathrm{C}$ prior to use.

\section{b. Analyses of Essential Oil by GC-MS.}

The oils were analyzed by gas chromatography-mass spectrometry (GC-MS) using an instrument Model Agilent $7890 \& 5975$ Series MSD. The some chromatographic conditions and MS operating parameters were identical to those used for the analysis of fresh and dried plant volatiles. (2.b). The different temperature program was the following: oven temperature was programmed as $40^{\circ} \mathrm{C}$ for 1 min and an increase by $5{ }^{\circ} \mathrm{C} / \mathrm{min}$ to $200{ }^{\circ} \mathrm{C}$. From $200{ }^{\circ} \mathrm{C}$ to $260{ }^{\circ} \mathrm{C}$, increase with $20{ }^{\circ} \mathrm{C} / \mathrm{min}$. It is maintained at $260^{\circ} \mathrm{C}$ for 10 minutes. The constituents of the volatile oils were identified by calculation of their retention indices under temperature -programmed conditions for C8-C20 standards alkanes (Alkane Standard Solution C8-C20, Sigma Aldrich) and the oil on HP 5-MS column in the same conditions. For compounds with RT $<5.690$ and RT $>29.978$, KI was reported from Nist Library Spectra.

\section{Results and discutions}

A total of twenty-eight compounds were identified representing $99,86 \%$ of the fresh aerial parts of Gallium verum herb. The floral bouquet of fresh flowers, Gallium verum comprised mainly oxygenated monoterpenes representing $73.57 \%$. The major components indentified were: 3-hexen-1ol-acetate (9.27\%); trans- $\beta$ ocimene (6.73\%), linalool (30.08\%); linalyl acetate (12.07\%); caryophyllene (6.89); A total of fifty compounds were identified representing $99.88 \%$ of the dried aerial parts of Gallium verum herb. The floral bouquet of dried flower, Gallium verum contains mainly: aldehydes, $35.48 \%$ monoterpenes $35.48 \%$, alcohols $11.96 \%$, sesquiterpenes, $3.71 \%$, acetates $3.14 \%$ and others $10.11 \%$. The major components indentified were, Gallium verum contains mainly: hexanal (4.98), Z-2-hexenal (12.75\%), 1-hexanol (7.90\%), eucalyptol (13.87\%), linalool (5.29\%), camphor (4.33). (Table 1).

Table 1. Volatile compounds identified in fresh and dried of galium verum plant

\begin{tabular}{|c|c|c|c|c|c|}
\hline \multicolumn{6}{|c|}{ SPME- GC-MS } \\
\hline & Compounds & RT & RI & $\begin{array}{l}\text { Fresh } \\
\%\end{array}$ & $\begin{array}{l}\text { Dried } \\
\%\end{array}$ \\
\hline 1 & Hexanal & 8.624 & 800 & - & 4.98 \\
\hline 2 & Z-2-Hexenal & 10.108 & 848 & - & 12.75 \\
\hline 3 & Z-3-Hexen-1-ol & 10.129 & 849 & 1.80 & - \\
\hline 4. & 1-Hexanol & 10.539 & 864 & - & 7.90 \\
\hline 5 & Heptanal & 11.494 & 900 & - & 1.70 \\
\hline 6 & $\alpha$-Pinene & 12.583 & 938 & - & 1.47 \\
\hline 7 & Camphene & 13.066 & 954 & - & 0.43 \\
\hline 8 & E-2-Heptenal & 13.154 & 957 & - & 1.85 \\
\hline 9 & Benzaldehyde & 13.372 & 965 & - & 2.17 \\
\hline 10 & 3-Octen-1-ol & 13.818 & 980 & - & 3.23 \\
\hline 11 & $\beta$-Pinene & 13.912 & 983 & - & 2.66 \\
\hline 12 & 3-Octanone & 14.062 & 988 & 3.12 & 1.90 \\
\hline 13 & $\beta$-Myrcene & 14.223 & 994 & 5.45 & - \\
\hline 14 & $(E, E)-2,4$-Heptadienal & 14.373 & 999 & - & 1.55 \\
\hline
\end{tabular}


Revista de Chimie

https://revistadechimie.ro

https://doi.org/10.37358/Rev. Chim.1949

\begin{tabular}{|c|c|c|c|c|c|}
\hline 15 & Octanal & 14.534 & 1004 & - & 0.81 \\
\hline 16 & 3-Hexen-1-ol-acetate & 14.659 & 1009 & 9.27 & 0.84 \\
\hline 17 & n-Hexylacetate & 14.804 & 1014 & - & 1.55 \\
\hline 18 & o-Cymene & 15.302 & 1031 & 0.26 & 0.77 \\
\hline 19 & d-Limonene & 15.406 & 1034 & 1.33 & 0.83 \\
\hline 20 & Eucalyptol & 15.520 & 1038 & - & 13.87 \\
\hline 21 & Trans-beta ocimene & 15.598 & 1041 & 6.73 & - \\
\hline 22 & Benzenacetaldehyde & 15.863 & 1050 & - & 2.41 \\
\hline 23 & Cis-beta-ocimene & 15.920 & 1052 & 4.23 & - \\
\hline 24 & E-2-Octenal & 16.200 & 1061 & - & 1.31 \\
\hline 25 & $\gamma$-Terpinene & 16.304 & 1065 & 0.32 & - \\
\hline 26 & Cis-linalooloxide & 16.714 & 1079 & - & 0.71 \\
\hline 27 & Trans-linalool oxide & 17.170 & 1094 & - & 0.55 \\
\hline 28 & Terpinolene & 17.201 & 1095 & 0.60 & - \\
\hline 29 & Linalool & 17.456 & 1104 & 30.08 & 5.29 \\
\hline 30 & Nonanal & 17.539 & 1107 & - & 3.55 \\
\hline 31 & 1-Octen-3-yl acetate & 17.710 & 1113 & 0.54 & - \\
\hline 32 & Phenylethyl alcohol & 18.083 & 1126 & - & 0.55 \\
\hline 33 & $(E, Z)$-allo-ocimene & 18.286 & 1134 & 1.80 & 0.42 \\
\hline 34 & $(E, E)$-allo-ocimene & 18.654 & 1147 & 0.45 & - \\
\hline 35 & Lilac aldehyde A & 18.720 & 1149 & - & 0.80 \\
\hline 36 & Cyclopentasiloxane,decamethyl & 18.835 & 1153 & - & 1.57 \\
\hline 37 & Camphor & 18.934 & 1157 & - & 4.33 \\
\hline 38 & E-2-Nonenal & 19.131 & 1164 & - & 1.03 \\
\hline 39 & Lavandulol & 19.391 & 1172 & 1.98 & - \\
\hline 40 & Pinocarvone & 19.406 & 1173 & - & 1.14 \\
\hline 41 & Terpinen-4-ol & 19.822 & 1188 & 3.89 & 0.39 \\
\hline 42 & Butanoic acid-hexyl ester & 19.972 & 1193 & 0.45 & - \\
\hline 43 & Methyl salicylate & 20.263 & 1204 & - & 0.75 \\
\hline 44 & Decanal & 20.382 & 1193 & - & 0.69 \\
\hline 45 & 3-p-Menthen-7-al & 20.994 & 1231 & - & 0.49 \\
\hline 46 & Linalyl acetate & 21.793 & 1261 & 12.07 & 0.34 \\
\hline 47 & E-2-Decenal & 21.918 & 1266 & - & 0.14 \\
\hline 48 & Lavandulyl acetate & 22.639 & 1293 & 1.22 & - \\
\hline 49 & Cyclopentasiloxane, dodecamethyl & 23.494 & 1326 & - & 2.75 \\
\hline 50 & Eugenol & 24.502 & 1366 & - & 0.77 \\
\hline 51 & Nerol acetate & 24.538 & 1368 & 1.03 & - \\
\hline 52 & Geranyl acetate & 25.015 & 1387 & 2.13 & 0.22 \\
\hline 53 & $\beta$-Bourbonene & 25.384 & 1401 & - & 0.74 \\
\hline 54 & $\alpha$-Santalene & 26.157 & 1433 & 0.42 & - \\
\hline 55 & Caryophyllene & 26.307 & 1440 & 6.89 & 1.89 \\
\hline 56 & Trans- $\alpha$-Bergamotene & 26.484 & 1447 & 0.32 & 0.11 \\
\hline 57 & Cis- $\beta$-Farnasene & 26.852 & 1462 & 2.25 & 0.45 \\
\hline 58 & Humulene & 27.096 & 1473 & 0.28 & 0.36 \\
\hline 59 & 1,15-Pentadecanediol & 27.719 & 1499 & - & 0.28 \\
\hline 60 & Squalene & 29.656 & 1597 & - & 0.16 \\
\hline 61 & 2,2,4-Trimethyl-1,3-pentanediol-diisobutyrate & 30.137 & 1606 & 0.55 & 0.76 \\
\hline 62 & Tetradecanal & 30.360 & 1616 & - & 0.54 \\
\hline \multirow[t]{2}{*}{63} & Di-n-octyl-ether & 31.167 & 1654 & 0.40 & 3.13 \\
\hline & Total & & & 99.86 & 99.88 \\
\hline
\end{tabular}

Extraction of essential oil from dried aerial part of Galium verum was carried out by hydrodistillation, using a Clevenger-type apparatus. Sixty components were identified in the essential oil of Galium verum representing to $26.84 \%$ aldehydes, $19.28 \%$ monoterpenes, $23.37 \%$ non-terpenehidrocarbons, $9.06 \%$ heterocycles, $7.78 \%$ organic acids, $6.1 \%$ sesquiterpenes, $7.29 \%$ others (Table 2 ) 
Table 2. Composition of essential oils of aerial parts of Galium verum

\begin{tabular}{|c|c|c|c|c|}
\hline \multicolumn{5}{|c|}{ HD-GC-MS } \\
\hline & Compounds & RT & RI & $\begin{array}{c}\text { Galium } \\
\text { verum } \\
\%\end{array}$ \\
\hline 1 & 3-Hexanone & 7.891 & 775 & 0.74 \\
\hline 2 & 2-Hexenal & 9.728 & 851 & 1.12 \\
\hline 3 & Benzene acetaldehyde & 15.560 & 1048 & 0.84 \\
\hline 4 & Benzofuran & 16.499 & 1079 & 1.33 \\
\hline 5 & Linalool & 17.132 & 1101 & 7.89 \\
\hline 6. & Nonanal & 17.277 & 1106 & 2.52 \\
\hline 7 & 2-Nonenal & 18.901 & 1162 & 0.40 \\
\hline 8 & Cinnamaldehyde & 19.456 & 1181 & 1.10 \\
\hline 9 & Alpha-terpineol & 20.027 & 1201 & 1.61 \\
\hline 10 & Decanal & 20.193 & 1207 & 0.98 \\
\hline 11 & Verbenone & 20.437 & 1216 & 0.61 \\
\hline 12 & Trans-p-mentha-2,8-diol & 20.733 & 1227 & 1.11 \\
\hline 13 & Linalyl acetate & 21.340 & 1249 & 2.30 \\
\hline 14 & 2-Decenal & 21.754 & 1264 & 0.89 \\
\hline 15 & Lavandulyl acetate & 22.227 & 1282 & 0.30 \\
\hline 16 & Tridecane & 22.724 & 1300 & 1.66 \\
\hline 17 & Undecanal & 22.959 & 1309 & 2.58 \\
\hline 18 & $(E, E)$-2,4-Decadienal & 23.291 & 1322 & 0.98 \\
\hline 19 & Geranyl acetate & 24.713 & 1377 & 1.72 \\
\hline 20 & Damascenone & 24.920 & 1385 & 0.49 \\
\hline 21 & $(E, E)$-2,6-Dimethyl-1,3,5,7-octatetraene & 25.067 & 1391 & 1.48 \\
\hline 22 & $\beta$-bourbonene & 25.164 & 1395 & 0.63 \\
\hline 23 & Tetradecane & 25.301 & 1400 & 1.26 \\
\hline 24 & Dodecanal & 25.564 & 1411 & 1.38 \\
\hline 25 & Caryophyllene & 26.098 & 1433 & 2.15 \\
\hline 26 & Furane-2-methyl-5-(1,1,5-trimethyl-5-hexenyl) & 26.337 & 1443 & 7.73 \\
\hline 27 & $\beta$-Famesene & 26.612 & 1454 & 0.74 \\
\hline 28 & 2,6,10-Trimethyl-tridecane & 26.752 & 1460 & 0.32 \\
\hline 29 & Humulene & 26.980 & 1469 & 0.45 \\
\hline 30 & Trans-beta-ionone & 27.369 & 1485 & 0.67 \\
\hline 31 & Pentadecane & 27.738 & 1500 & 1.25 \\
\hline 32 & Tridecanal & 28.028 & 1513 & 1.06 \\
\hline 33 & 1,8-(2H,5H)-Naphthalenedione,hexahydro-8a-methyl,cis & 28.275 & 1523 & 1.41 \\
\hline 34 & Lilial & 28.526 & 1534 & 0.33 \\
\hline 35 & Caryophyllene oxide & 29.995 & 1598 & 0.74 \\
\hline 36 & Tetradecanal & 30.368 & 1615 & 6.00 \\
\hline 37 & Tau-cadinol & 31.219 & 1654 & 2.87 \\
\hline 38 & Heptadecane & 32.233 & 1700 & 0.71 \\
\hline 39 & Pentadecanal & 32.579 & 1719 & 2.96 \\
\hline 40 & Tetradecanoic acid & 33.372 & 1761 & 0.76 \\
\hline 41 & Hexadecanal & 34.358 & 1821 & $\mathbf{3 . 3 3}$ \\
\hline 42 & 2-Pentadecanone,6,10,14-trimethyl & 34.654 & 1845 & 1.27 \\
\hline 43 & Nonadecane & 35.333 & 1900 & 0.48 \\
\hline 44 & Heptadecanal & 35.541 & 1922 & 0.46 \\
\hline 45 & n-Hexadecanoic acid & 35.904 & 1961 & 6.49 \\
\hline
\end{tabular}




\begin{tabular}{|l|c|c|c|c|}
\hline 46 & Hexadecanoic acid, ethyl ester & 36.190 & 1992 & 0.43 \\
\hline 47 & Eicosane & 36.267 & 2000 & 0.56 \\
\hline 48 & Octadecanal & 36.470 & 2037 & 1.01 \\
\hline 49 & $Z$-10-Heneicosene & 36.911 & 2060 & 0.34 \\
\hline 50 & Heneicosane & 37.129 & 2100 & 1.46 \\
\hline 51 & Phytol & 37.285 & 2128 & $\mathbf{3 . 4 4}$ \\
\hline 52 & (Z,Z)-9,12-octadecadienoic acid & 37.762 & 2147 & 0.53 \\
\hline 53 & Docosane & 38.037 & 2200 & 1.23 \\
\hline 54 & $Z$-9-Tricosene & 38.789 & 2274 & $\mathbf{3 . 1 1}$ \\
\hline 55 & Tricosane & 39.044 & 2300 & $\mathbf{5 . 9 4}$ \\
\hline 56 & Tetracosane & 40.221 & 2400 & 0.51 \\
\hline 57 & Hexacosane & 41.088 & 2600 & 0.40 \\
\hline 58 & Heptacos-1-ene & 41.233 & 2673 & 0.59 \\
\hline 59 & Heptacosane & 45.695 & 2800 & 0.67 \\
\hline 60 & Ocatacosane & & $\mathbf{9 9 . 7 2}$ \\
\hline
\end{tabular}

The major components are: linalool (7.89\%), Furane-2-methyl-5-(1,1,5-trimethyl-5-hexenyl) (7.73\%), tetradecanal $(6.00 \%)$, caryophyllene $(2,15 \%)$, hexadecanal $(3.33 \%)$, n-hexadecanoic acid (6.49\%), phytol (3.44), 9-tricosene (3.11\%), tricosane (5.94\%).

From the study of the profile of the volatiles, we observed the considerable differences between the volatiles extracted from the fresh, dried plant and the essential oil obtained from the same plant. (Fig. 1.)

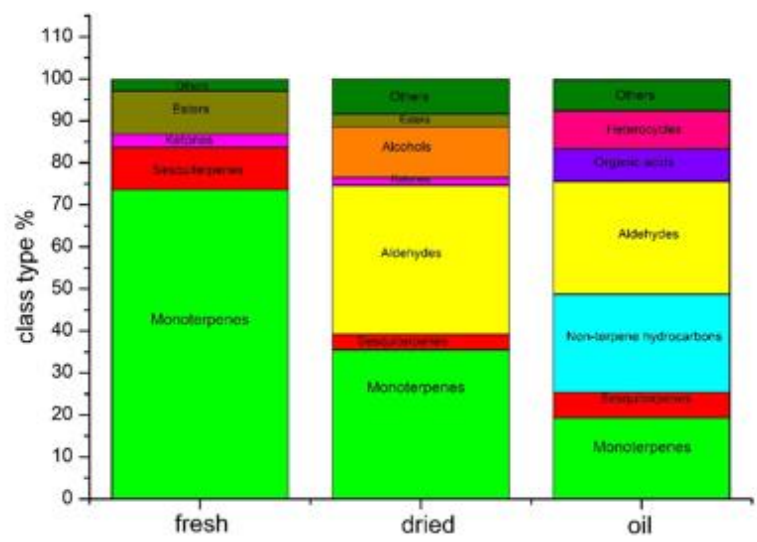

Figure 1. Class type found in the aerial part fresh, dried and oil in Galium verum by SPME and HD methods

From Figure 1 we observe in the oil a decrease of the content of monoterpenes (19.28\%) compared to the content in monoterpenes from fresh $(73.57 \%)$ and dry $(35.48 \%)$. The gallium fresh flower has a scented odor, due to the presence of monoterpenic compounds in percentage of $73,75 \%$. Linalool and linalyl acetate are common floral volatiles widely used in pharmaceutical industry due to bioactive properties demonstrated (anti-inflammatory, anticancer, anti-hyperlipidemic, antimicrobial, antinoceptive, analgesic, anxiolytic, antidepressive and neuroprotective), [31, 32], in cosmetical industry (perfumes, shampoos, among others) due to pleasant aroma [33], are involved in communication and protection through plant-pollinator interactions [34]. Numerous therapeutic uses of $\boldsymbol{\beta}$-caryophyllene have been discovered, with the molecule displaying analgesic, antibacterial, antidepressant, anti-inflammatory, antiproliferative, antioxidant, anxiolytic, and neuroprotective actions. [35]. $\boldsymbol{\beta}$-Ocimene is one of the most present volatile in floral scents and can play very relevant roles in the attraction of several types of pollinators to the flowers of a diverse array of plants. [36] Because the fresh plant contains many terpenes including linalool, linalyl acetate, caryophylene, b- 
ocimene, with demonstrated bioactive properties, a pharmaceutical or cosmetic formula for using the plant in fresh form may be found. The literature suggests the use of glycerin as an embedding matrix for fresh plants because it preserves them very well. [15, 37]

After drying the plant, the content of monoterpenic compounds that give off the fresh odor decreases, which are very volatile. The dried gallium flower has a grassy smell, due to the presence of green leaf volatiles (aldehydes, alcohols, acetates) specific to green plants and slightly mentholated due to camphor and eucalyptol. [38]. The dried material has a smaller sample of mass variation compared to the fresh plant and therefore contains a more predictable amount of stable active principles. So, on the market are found medicinal products from the dried gallium herb such as: teas, macerates, tinctures, creams with anti-inflammatory, anti-tumor, emollient, healing and antibacterial properties. [39]

There are few studies on the composition of the composition of Gallium verum oil. [22-24]. The oil isolated by hydro-distillation from the aerial parts of Galium verum contain: non-terpene hydrocarbons, organic acid and heterocycles, which are not present in the fresh and dried plant. These compounds are formed after distillation due to reactions caused by light, heat and oxygen when some terpenes, alcohols and aldehydes are converted to organic acids by hydrolysis and oxidation. [39] The new compounds were found in oil, which were not reported in the literature: furane-2-methyl-5-(1,1,5trimethyl-5-hexenyl) (7.73\%), tetradecanal (6\%), hexadecanal (3.33\%), tricosane (5.94), 9Z-tricosene $(3.11 \%)$, etc. Essential oils have wide variety of bioactivities and play an important role as ideal natural sources of antimicrobial, antioxidant and chemopreventive agents. [41, 42].

This diversity of content gives the plants multiple healing, beauty and even immunization properties to different diseases, which justifies its reputation as a magic plant.

\section{Conclusions}

In the present study, $\mathrm{VOC}_{\text {s }}$ profile in Gallium verum fresh, dried and essential oil, were extracted using SPME and HD techniques, followed by GC-MS analysis. The Gallium verum herb was harvested from spontaneous Romanian flora.

- From the study of the Galium verum VOCs, we observed the considerable differences between the volatiles extracted from the fresh, dried plant and the essential oil obtained from the same plant.

- The differences in the extraction techniques applied resulted in differences in the extracted essential oil, such as considerably higher quantity of the monoterpenes adsorbed on SPME than in the HD oil.

- A literature search did not show any reference to previous work on the characterization of volatile profile from fresh and dried Galium verum by SPME-GC-MS technique.

- The new compounds were found in essential gallium oil, which were not reported in the literature: furane-2-methyl-5-(1,1,5-trimethyl-5-hexenyl) $(7.73 \%)$, tetradecanal $(6 \%)$, hexadecanal $(3.33 \%)$, tricosane $(5.94)$, 9Z-tricosene $(3.11 \%)$, etc.

- Because the fresh plant contains many terpenes including linalool, linalyl acetate, caryophylene, $\beta$-ocimene, with demonstrated bioactive properties could be proposed, a pharmaceutical or cosmetic formula that uses fresh plant.

\section{References}

1.SAVULESCU, T., Flora Romaniei, Ed. Academiei RSR, VIII, 1961, p. 565.

2.CIOCARLAN, V., Flora ilustrată a Romaniei, Ed. Ceres Bucuresti, 2000, p. 738.

3.ZHAO, C.C, SHAO, J.H, LI, X., KANG, X. D., ZHANG, C. C., MENG, D.L., Li, N., Nat Prod Res.; 20, 2006, p. 981.

4.BÖJTHE-HORVATH, K., KOCSIS, A., PARKANY, L., SIMON, K., Tetrahedron Lett. 23, 1982, p. 965, DOI:10.1016/S0040- 4039(00)86995-6

5.MITOVA, M.I., ANCHEV, M.E., HANDJIEVA, N.V., POPOV, S.S., Zeitschrift Fur Naturforsch. J. Biosci. 57, 2002, p. 226, DOI: 10.1515/znc-2002- 3-405. 
6.MATEI, A.O, GATEA F., RADU, G.L, J Chromatogr Sci, 53; 2015, p.1147.

7HANGANU D., BURTESCU R. F., PETRESCU S., PRIPON FURTUNA F.R, CHIȘE E., TURCUȘ, V.,.BENEDEC, D ONIGA I., OLAH N.K., Hop and Medicinal Plants, XXVI, no. 1-2, 2018, p. 84.

8.MATEI, A. O., GATEA, F., TEODOR E. D., RADU, G. R., Rev.Chim., 67, (6), 2016, 1051.

9.ZHAO, C.C., SHAO, J.H., ZHAO, C.J., LI X., Chemistry of Natural Compounds; 47, 2011, p. 545.

10.TAMAS, M., STANA, D., TIMIS, S., Not Bot Agrobot Cluj, XXXIV, 2006, p.18.

11.BRADIC, J., PETKOVIC, A., TOMOVIC, M., Serbian Journal of Experimental and Clinical Research, Review Paper, 2017, p. 1, DOI: 10.1515/SJECR.2017.0057

12.LAKIĆ, N. S., MIMICA-DUKIĆ, N. M., ISAK, J. M., BOZIN, B. N., Central European Journal of Biology, 5, no. 3, 2010, p. 331.

13.VASILEVNA, I. T., VOLODYMYRIVNA, G. O., LEONIDIVNA, T. E., ALEKSANDROVNA, K. I., MIHAYLOVNA, K. A., Pharmacogn. Commn, 6, no 1, 2016, p. 142.

14.ESMAIL AL-SNAFI, A., Indo American Journal Of Pharmaceutical Sciences, 5, no 4, 2018, p. 2142.

15.KUMADOH, D., OFORI-KWAKYE, K., Journal of Critical Reviews, 4, no. 4, 2017, p. 1.

16.JOVANOV, D., Integrative Food, Nutrition and Metabolism, 4, 2017, p. 1.

17.ARTHUR, C.L, PAWLISZYN J., Anal Chem. 62, 1990, p. 2145

18.BALEA, A., POJAR FENESAN M., CIOTLAUS, I., Rev.Chim., 69, (9), 2018, 2529.

19.AZWANIDA N.N., Med Aromat Plants, 4, 2015, p.196 DOI:10.4172/2167-0412.1000196.

20.BELliARDO, F., BICCHI, C., CORDERO, C., LIBERTO, E., RUBIOLO, P., SGORBINI, B., Journal of Chromatographic Science44, 2006, p.416.

21. SZÉKELYHIDI, R., Journal of Medicinal Plants Studies, 5, no 4, 2017, p. 103.

22.MIRZA, M., NAJAFPOUR -NAVAEI M., DINI M., Iranian Journal of Pharmaceutical Research, 3, 2004, p. 88.

23.Il'INA, T.V., KOVAlEVA, A.M., GORYACHAYA, O.V., ALEXANDROV, A.N., Chem Nat Compd. 45, 2009, p. 587.

24.SOLEIMANI, M., ALI ZADE, A., First National Chemistry and Nanotechnology Conference. Rasht Branch, Islamic Azad University, Guilan, Iran, December, 2014, p 1.

25.REHMAN, S., LATIEF, R., BHAT K. A., KHUROO M. A., SHAW, A. S., CHANDRA, S., Arabian Journal of Chemistry, 10, 2017, , p. S2485

26.FAROUK, A., ALI, H. A., AL-KHALIFA, R., MOHSEN, M., FIKRY, R., International Journal of Food Properties, 22, no.1, 2019, p. 395, DOI:10.1080/10942912.2019.1588901

27.MUSElli, A., PAU, M., DESJOBERT, J. M., FODDAI, M., USAI, M., COSTA, J., Chromatographia, 69, 2009, p. 575, DOI: 10.1365/s10337-008-0939-1

28.NEKOEI, M., MOHAMMADHOSSEINI, M., AKHLAGHI, H., Journal of Essential Oil Bearing Plants, 15, no. 6, 2012, p. 926

29.WAJS A., PRANOVICH, A., REUNANEN, M., WILLFOR, S., HOLMBOM, B., Phytochemical Analysis 17, 2006, p. 91, DOI: 10.1002/pca.891

30.MOHEBAT R., BIDOKI Z. M., Royal Society Open Science, 5, 2018, p. 1.

31.PEREIRA, I., SEVERINOC, P., SANTOSA, A. C., SILVA, A. M., SOUTOA E. B., Colloids and Surfaces B: Biointerfaces, 171, 2018, p. 566

32.PEANA, A.T, D'AQUILA, P. S., PANIN, F., SERRA, G., PIPPIA, P., MORETTI, M.D., Phytomedicine, 9, no. 8, 2002, p. 721

33.APROTOSOAIE, A.C., HĂNCIANU, M., COSTACHE, I. I., MIRON, A., FLAVOUR FRAGR. J., 29, 2014, p.193

34.RAGUSO, R. A., Current Opinion in Plant Biology, 32, 2016, p. 31

35.LEGAULT, J., PICHETTE A., J. Pharm Pharmacol. 59, no. 12, 2007 p.1643

36.FARRE-ARMENGOL G., FILELLA I., LLUSIA J., PENNUELAS, J., Molecules, 22, 2017, p. 1148 ; 
37.BASCOM, A., Incorporating Herbal Medicine into Clinical Practice. Philadelphia: F. A. Davis Company; 2002, p.1.

38.SCAlA, A., AllmanN, S., MiRABElla, R., HARING, M. A., \& SCHUURINK, R. C., International Journal of Molecular Sciences, 14, no. 9, 2013. p. 17781

39.DJORDJEVIC, S. M., Aromatic and Medicinal Plants - Back to Nature, 16, 2017, p. 270

40.FIGUEIREDO, A. C., BARROSO, J. G., PEDRO, L. G., \& SCHEFFER, J. J., Flavour and Fragrance journal, 23, no. 4, 2008. p. 213

41.FRANZ, C., NOVAK J., Science, Technology, and Applications CRC Press, Boca Raton, FL, USA, 2010, p. 39

42.GHERMAN, T., POPESCU, V., CARPA, R., RAPA, M., GAVRIL, G. R., DUDESCU M.C., BOMBOS D., Rev.Chim., 69, (3), 2018, 575.

$\overline{\text { Manuscript received: } 12.12 .2019}$ 